DOI: https://doi.org/10.47405/mjssh.v6i11.1150

\begin{tabular}{|c|c|}
\hline 4 & Malaysian Journal of Social Sciences and Humanities (MJSSH) \\
\hline $\begin{array}{l}\text { Malaysian Juoural of } \\
\text { Social ccciecces and }\end{array}$ & Volume 6, Issue 11, November 2021 \\
\hline (MJ-sSH) & e-ISSN : 2504-8562 \\
\hline & $\begin{array}{l}\text { Journal home page: } \\
\text { www.msocialsciences.com }\end{array}$ \\
\hline
\end{tabular}

\title{
Customer Satisfaction on the Quality of Services of Local Skin Care Products
}

\author{
Wan Nur Afiqah Binti Wan Abd Hamid', Muhammad Syahmi Bin Azahari', \\ Noor Maisarah Binti Mohd Noor Azam¹, Nur Aimie Kamalia Binti Kamalrozaman', \\ Nurdiyana Binti Che Kamal1, Phoebe Cherng Fei Min'1, Vimala Davy G. Ramiah², Sio Ching Hee ${ }^{3}$, \\ Isai Amutan Krishnan4 \\ 1University of Malaya Centre for Continuing Education (UMCCeD), Malaysia \\ ${ }^{2}$ Institute Aminuddin Baki, Sarawak Branch, Kuching, Sarawak, Malaysia \\ ${ }^{3}$ ELM Business School, HELP University, \\ Jalan Sri Semantan 1, Off Jalan Semantan, Bukit Damansara, 50490 Kuala Lumpur, Malaysia \\ ${ }^{4}$ School of Liberal Arts, Science and Technology, PERDANA University, Suite 5.3 5th Floor Wisma Chase Perdana Jalan \\ Semantan Damansara Heights, Wilayah Perseketuan, Malaysia \\ Correspondence: Isai Amutan Krishnan (amuthanisai@gmail.com)
}

\begin{abstract}
The purpose of this research is to find out more information on the satisfaction of customers on the quality of services of local skincare products. Quality is the most important element that is closely related to the satisfaction of a customer. The chosen brand that has been observed for this research is NSA Beau that is formulated from their own serum called the AINAA Serum. Customers face difficulties regarding the availability and quality of skin care products. Besides that, the local industries in skincare products are also facing problems such as low-quality products, that influence the perspective of the person. This includes bad reviews due to their ineffectiveness on certain people who have a certain type of skin. It is suggested that the level of quality of service is an indication of the organization's ability to meet the desires and demands of customers'. Therefore, the objective of this study is to examine customer satisfaction based on their perceptions of local skincare products based on its quality. It also indicates the discovery of the local skincare products in Malaysia that are used by the society on a daily basis. Hence this research examines the reliability of these local skincare products. Online surveys were conducted on university students and working adults in Malaysia to find their perspectives and opinions on the quality of a brand when the brand is used, the effectiveness of its promotion, the image of the brand and its preference. It can be seen that quality is the most important factor for a person to buy especially a skincare product. The research also shows that there are specific important reasons in decision making to purchase a skincare product. An example is the effectiveness of the brand especially its quality, advertisement of the product, the image the brand holds and other reasons that effect the variables.
\end{abstract}

Keywords: customer satisfaction, quality of service, local skin care product

\section{Introduction}

Conducting a customer satisfaction survey is a good way to start measuring where a brand stands in terms of customer loyalty. Paul Hague and Nick Hague, Customer Satisfaction Surveys \& Research: How to Measure CSAT. Quality is the most important element closely related to customer satisfaction. The brand that this research is looking through is called NSA beau. It started on the $20^{\text {th }}$ of January 
2018. Based on the company's website, it is said that the first step in the business was when they decided to formulate their own serum called AINAA Serum from an established cosmetic manufacturer based in Malaysia. There has been a lot of disagreement and uncertainty of product quality from the society. Salmi Mohd Isa. (2005), Service Quality and Its Relationship with Customer Satisfaction towards Customer Loyalty: Perceptions of Public Listed Companies. The study also looked into the difficulties faced by the customers with regard to the availability and quality of skin care products and their overall satisfaction level. The local skincare products industry has faced many problems such as poor quality of products that has brought disappointment, and bad reviews on skin problems by the effects of the product which has decreased the satisfaction of customers. Therefore, the objectives of this study are to examine customer satisfaction of local skincare products based on quality and to discover the local skincare situation in Malaysia.

\section{Literature Review}

First of all, here are a few past studies on factors that influence Malay students in purchasing skincare products in Malaysia (Shima Rani \& Devi Krishanan. 2018). It shows that most of the Malay students considered Halal status, product safety of a product, brand, price, and quality as the most important factors when purchasing skin care products. There is also another study on the factors that influence the buying behaviour of cosmetic products among consumers (Anjana SS \& Amrita Vidyapeetham, 2018)). The results show that there are a few factors that influence customer to purchase a product such as quality, brand, price, advertisement and packaging.

Besides that, there is another study on customer satisfaction and loyalty (KabuKhadka \& Soniya Maharjan. 2017)). Its result shows that the satisfaction of certain customers is based on cultural, social, personal, and psychological factors. Furthermore, there is another study that has investigated the critical success factor of brand loyalty (Shahida Aziz, Shahar Jusoh \& Harith Amlus, 2017). The study found that the quality of a product, service quality, value and image, among others are factors that influence brand loyalty. Brand loyalty can be conceptualized with measurable dimensions and tested in future empirical studies as a model of fitness.

Next, a study on customer satisfaction, service quality, and customer value from 2000-2015 was conducted by Haemoon, Kim, O. K. (2017)). For the past three decades, Oh \& Park (1997), Rao \& Monroe (1989) and Yi (1993) found customer satisfaction, service quality, and customer value as the most important indicators of customer experience with products and services.

Brand loyalty is an important aspect which keeps the business running (Chan, Yin, Y., \& Shaheen Mansori, 2016)). A study was conducted made by them on factors that influence consumers' brand loyalty toward cosmetic product. Their result showed that there was a relationship between brand loyalty with special focus on brand image, quality, price and promotion.

Other than that, this is a study on the influence of attitude of consumers' behavioural intention toward Halal cosmetic products in Malaysia (Bayah Ahmad \& Azizah Omar, 2016)). In this research they found that most of customer are aware of Halal certification on skin care products and choose them. On the other hand, there is also a study on factors that influence customers' satisfaction and brand loyalty in cosmetic products among students (Aishah Ahmad \& Merduwati Hashim, 2016)). They have identified a few results like students tend to change the brands of cosmetic products; lack of awareness of the impact of cosmetic products to their health among them and lack of information in cosmetic products.

Past studies have also been conducted on customer loyalty that is considered as the outcome of a process beginning with customer satisfaction (Oliver. (1999)). There are other factors besides customer satisfaction that determines customer loyalty such as personal determinism and social factors. But satisfaction is a necessary step in loyalty formation (Oliver. (1999)). Furthermore, a study was conducted by Eftimiya Salo (2014) on "Consumer Behaviour Toward Green Skin Care Cosmetic Product in Finland". The result showed the customer's behaviour toward the product such as natural 
ingredient, general interest toward the skincare product, life situation, and their annual income. Last, Zohora Kabir (2013) did a study on "Factor Affecting Consumer Preferences for Purchasing a Skincare Product." The result show there are significantly relationships between the willing to pay for a skincare product and the price factor of a skincare product, relationship between the desire to spend on skin products and brand factor.

Most of the past studies have contributed towards their research. However, among of these research there is a gap that may filled by other skincare products that may deal with the perception of public towards skincare products. It will give a great opportunity to create a good brand image if the customers are satisfied with the product.

Other than that, not many of the customers get an important icon to know the quality of the product. The use of well-known icon will lift up the brand name and customers will be more satisfied if the icon is beautiful after using the product. It will influence them as the product review is guaranteed.

\section{Definitions}

\section{Customer Satisfaction}

A customer talking about his /her experience with you is worth ten times more that which you write or say about yourself (Greer, 2015). Previous research has stated that customer satisfaction is the biggest impact to a business. It is crucial to satisfy their needs because it either builds or collapses a business.

\section{Quality}

Quality is remembered long after the price is forgotten (Gucci, 1936). Quality affects the customer's reaction to a product. Whatever the price, they are more concerned on the products effectiveness.

\section{Local Skincare Products}

A glowing skin is a result of proper skin care. It means you can wear less make up and let skin shine through (Coulombe, 2014). In the era we live in now, skincare is a top priority in society, especially for women. People put in time and money to find the perfect product for their skin.

There is a interrelationship between customer satisfaction, quality and local skincare products because these usually have a bad reputation, therefore it is no surprise that customers hesitate to purchase them. With accusations of damaging chemicals, it is not surprising local products have to strive for recognition. Gucci stated that the quality of a product is remembered long after the price is forgotten, hence side effects of a product contributes to the success or failure of a business'. This relates to customer satisfaction stated is by Greer in 2015 as we live in a world where "the customer is always right" which influence customer satisfaction towards the quality of a local skincare product.

\section{Methodology}

A survey will be conducted to university student and working adults in Malaysia to test hypotheses for this research. The quantitative research methodology approach will be used in this research which conducted by online survey. The instrumentation for this study has been designed based on the research objectives and questions. Thus, the data for the study will be collected via online survey questionnaire. The evaluation form will be used as a questionnaire. It will be designed in an English version for the ease of the respondents. The content of the questionnaire consists of first part which is Section A will solicit relevant personal information, such as participant's age, gender, educational level, occupation, monthly income, race, marital status and brand of skin care they use. Second part that is Section B will be divided into four factors and this question will measure using SERVQUAL model that is questionnaire, survey and testimony. This will be according to a a five-point Likert scale ranging from 1 (strongly disagree) to 5 (strongly agree) to be selected from their responses. 


\section{Conceptual Framework}

The conceptual framework that was proposed as above is based on Lanza, K. M. (2008), Jamal, A. (2001), Satendra Thakur and A.Singh (2012) and has been altered and modified. This research focuses on the local skin care products of customer perception on the quality of the product, promotion, image and preferences. These four factors of customer's perceptions are the independent variables; and the one dependent variable is customer satisfaction. In this study, the relationships between factors of these four independent variables and the customer satisfaction on local skin care products have been examined throughout Malaysian and linked with four hypotheses.

Figure 1: Conceptual Framework

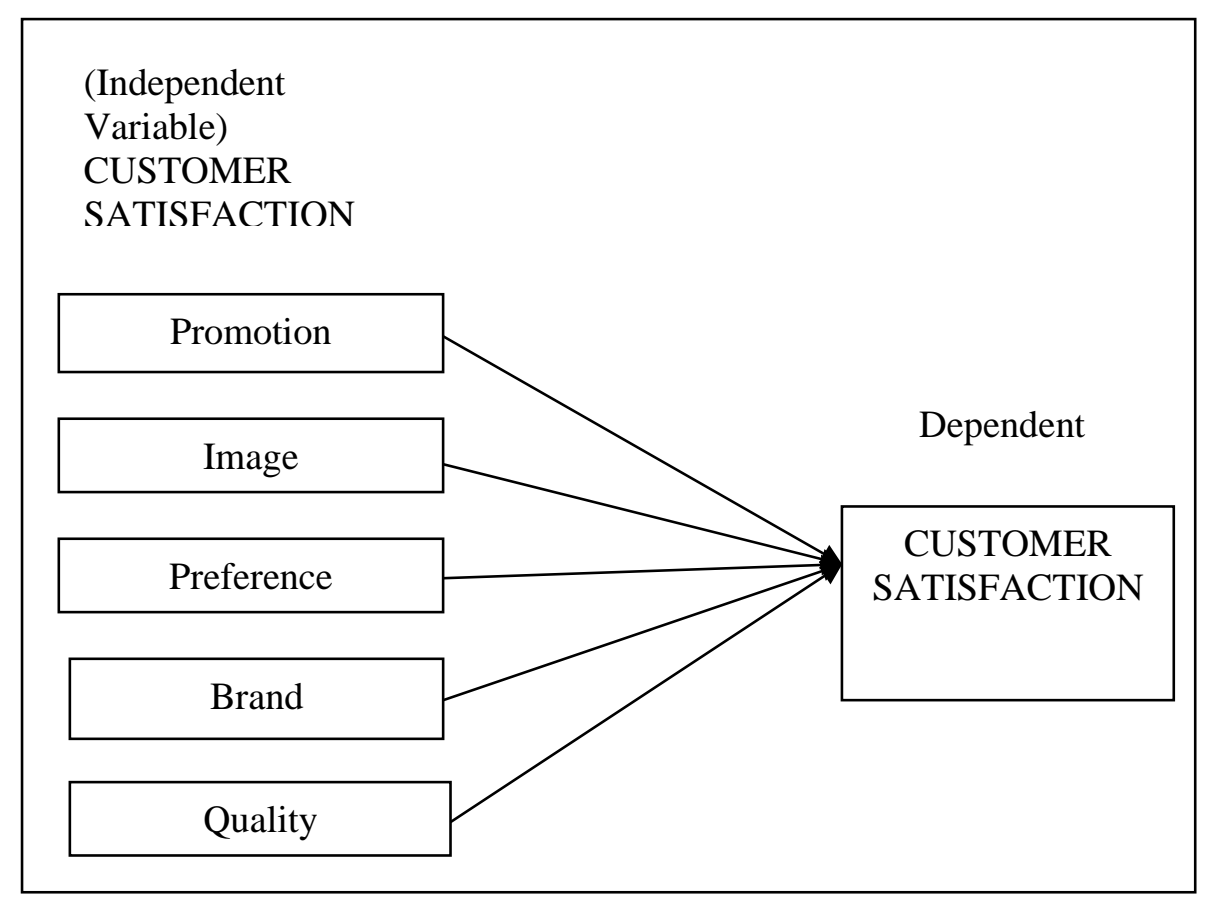

\section{Results}

\section{Respondent Demographic Profile}

Figure 2 shows that the respondents who use skin care product in the survey. $81 \%$ of the respondents agreed, and 19\% disagreed and did not use skin care products.

Figure 2: Do you use skin care products

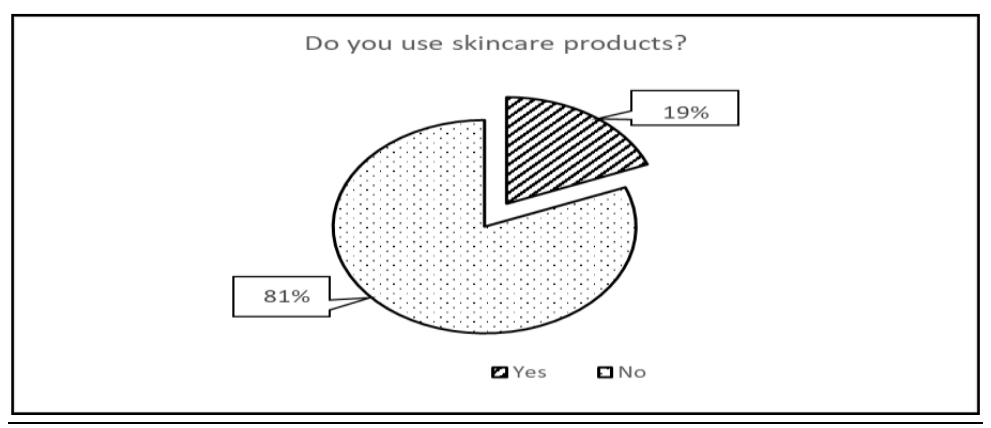

Figure 3 shows the gender of respondents who participate in this survey. Out of 377 respondents, 32\% of the respondents are male and $68 \%$ of the respondents are female. 
DOI: https://doi.org/10.47405/mjssh.v6i11.1150

Figure 3: Gender distribution of the respondents

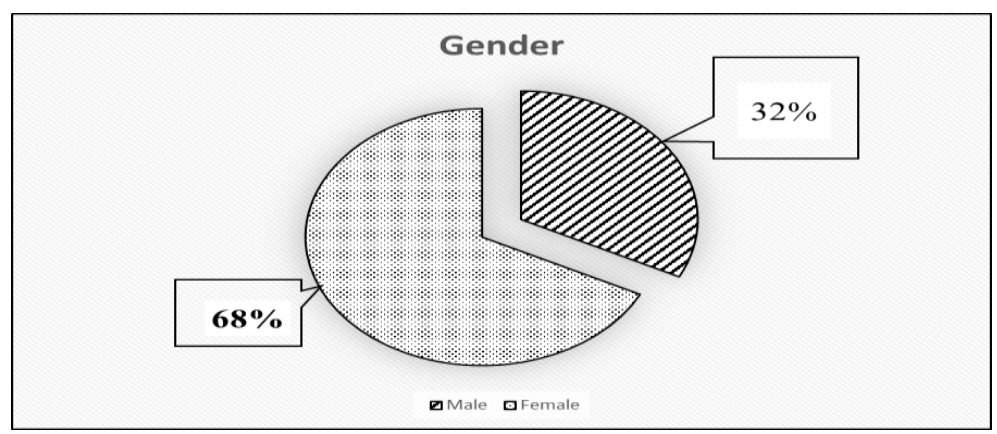

Figure 4 revealed that majority of the respondents are Malay which comprises $70 \%$. Besides, $21 \%$ of the respondents are Chinese, $8 \%$ of the respondents are Indian and $1 \%$ respondents of the are others.

Figure 4: Race distribution of the respondents

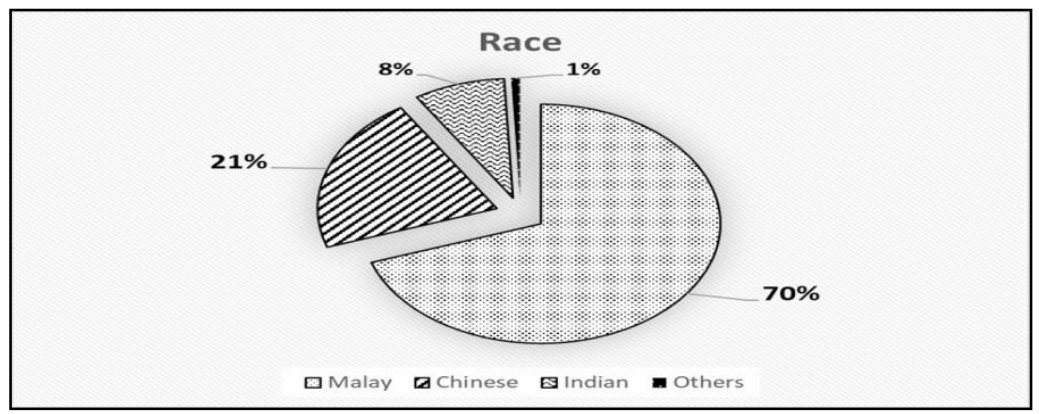

Referring to Figure 5, 84\% of the respondents reported were in the age of $18-30$ years old, $11 \%$ of the respondents were between the ages of 31-49 years old, and 5\% of the respondents between 50 and 60 years old.

Figure 5: Age distribution of the respondents

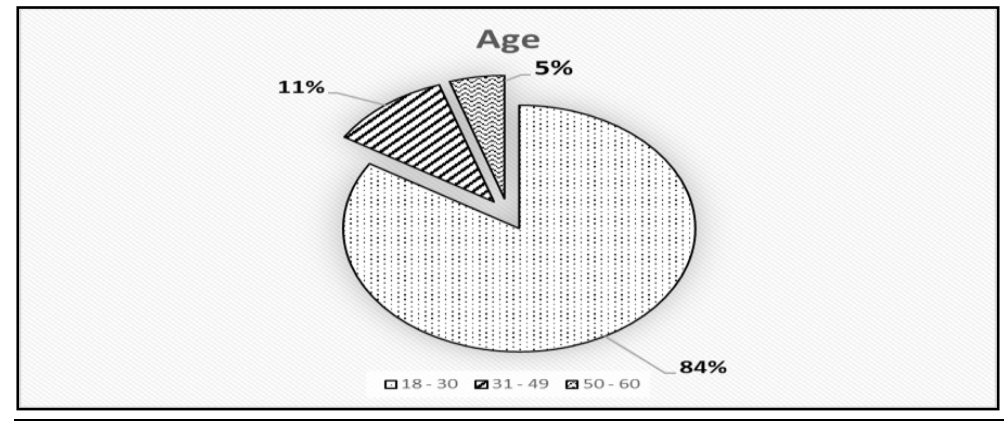

Based on the Figure 6 , it shows that $83 \%$ of the respondents are single, $15 \%$ of the respondents are married, and $2 \%$ of the respondents are divorced.

Figure 6: The marital status of the respondents

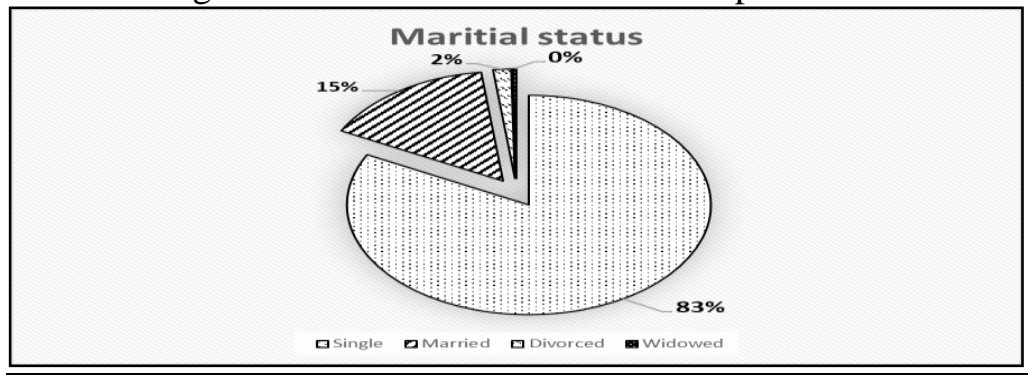


Based on Figure 7, the results revealed that $45 \%$ of the respondents have SPM, $28 \%$ of the respondents have STPM or Pre-U or Diploma, 9\% of the respondents have Bachelor Degrees, 1\% of the respondents have Masters and 17\% of the respondents have Phds.

Figure 7: Level of Education respondents

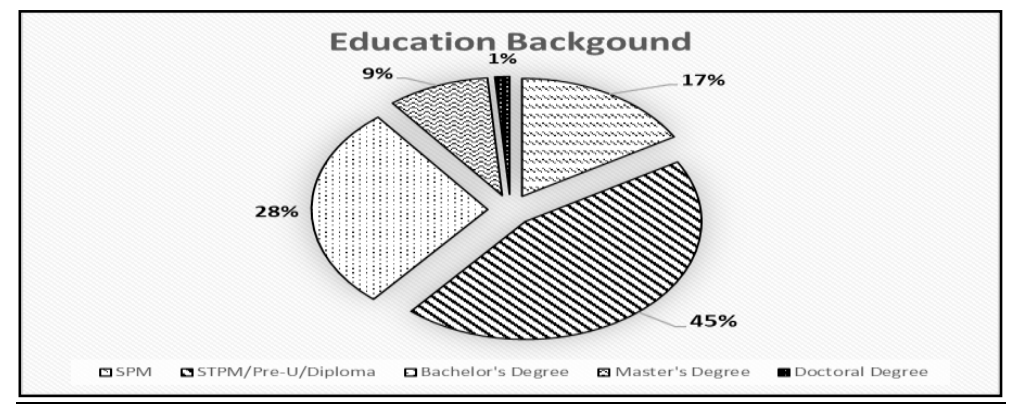

Referring to the Figure 8, the analysis of respondents' occupation. It shows that the employed category consists of $89 \%$ of the respondents, unemployed category consists of $2 \%$ of the respondents, homemaker category consists of $1 \%$ of the respondents, students consists of $3 \%$ of the respondents, Freelancers consist of $2 \%$ and a $3 \%$ of the respondents belong those who are retired.

Figure 8: The occupational distribution of respondents

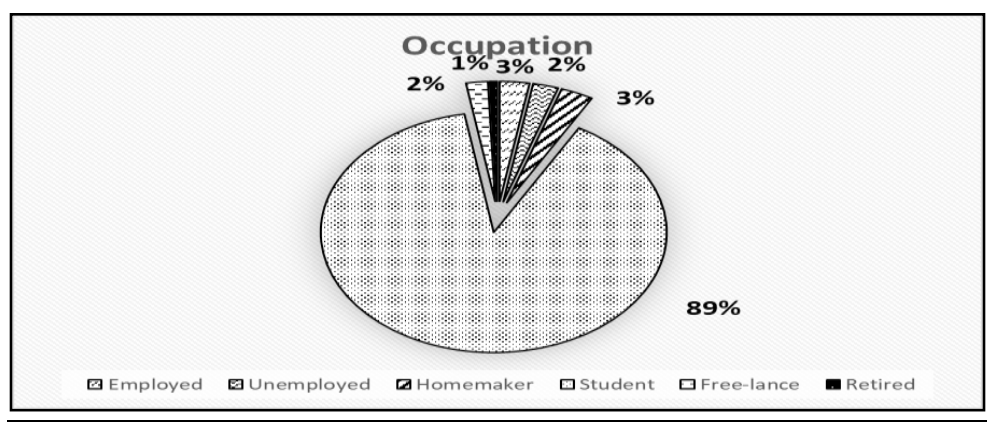

As shown in Figure 4.8, the results revealed that $65 \%$ of the respondent's income was less than RM1000 and $11 \%$ of the respondents had income of RM1001 to RM2000. Besides that, $95 \%$ of the respondents had income from RM2001 to RM3000. Where else, 8\% of the respondents earned between RM3001 and RM4000 and followed by 7\% of the respondents who had an income above RM4000

Figure 9: The monthly income or allowance per month of respondents

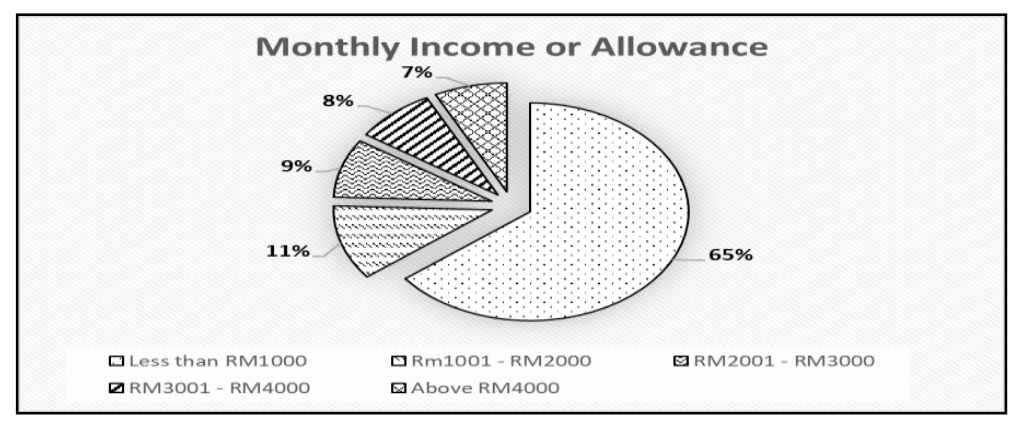

Figure 10 shows the respondents' choice of skin care product. There were $37 \%$ of the respondents who used other skin care products not in the survey list. Besides that, $18 \%$ of the respondents are using 
Garnier, $7 \%$ of the respondents are using L'oreal, $19 \%$ of the respondents are using Nivea, $14 \%$ of the respondents are using body shop and 5\% of the respondents are using Avon.

Figure 10: Brand of Products

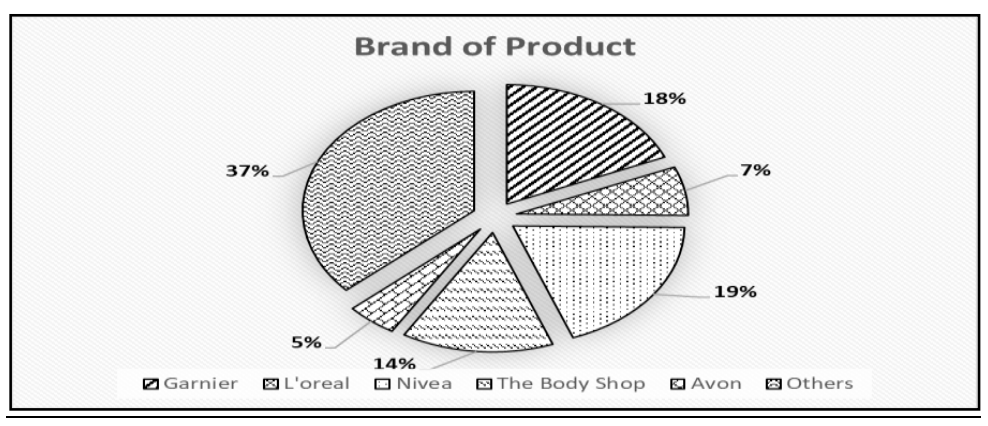

As it is shown in figure 11 , the result shows $45 \%$ of the respondent agree to the perception of quality of the brand. Besides, $26 \%$ respondents of the strongly agreed and $25 \%$ respondent choose to be neutral to the perception of the brand. Where else, $3 \%$ of respondent disagreed and $1 \%$ of the respondent strongly disagreed.

Figure 11: The Brand Perception on Quality Skin Care Product

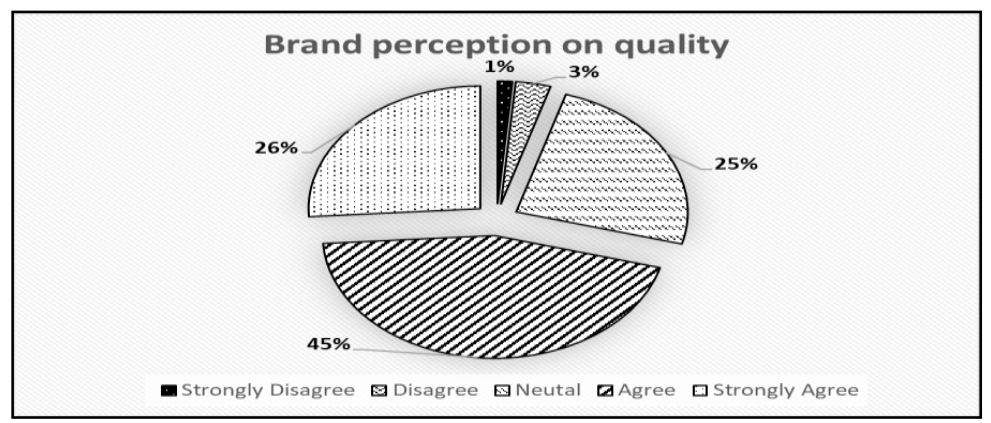

As it is shown in figure 12, the result show $38 \%$ of the respondents agreed to the perception of brand promotion. Besides, $32 \%$ of the respondents are Neutral and $16 \%$ of the respondents strongly agree to the perception on brand promotion. Where else, $11 \%$ of the respondents disagreed and $3 \%$ of the respondent strongly disagree.

Figure 12: The Brand Perception on Promotion

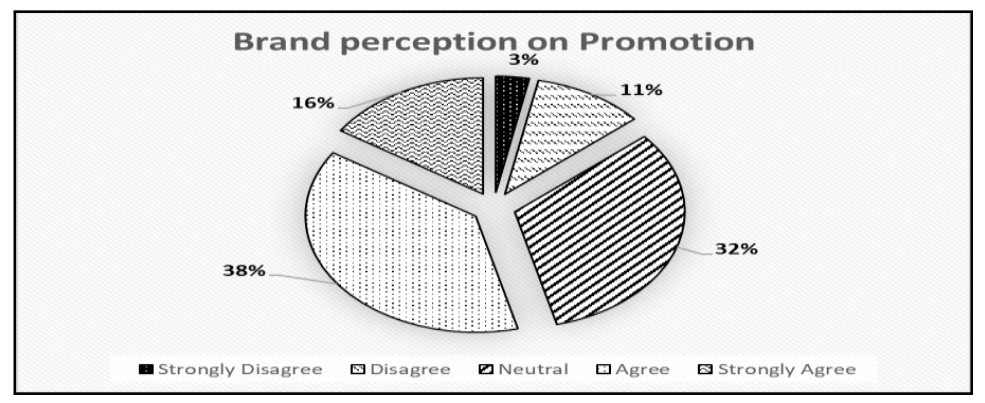

As it is shown in figure 13, the result show $45 \%$ of the respondents agree to the perception of brand image. Besides, $31 \%$ of the respondents are Neutral and $16 \%$ of the respondents strongly agree to the perception on brand image. Where else, $6 \%$ of the respondents disagree and $2 \%$ respondent strongly disagree. 
Figure 13: The Brand Perception on Image

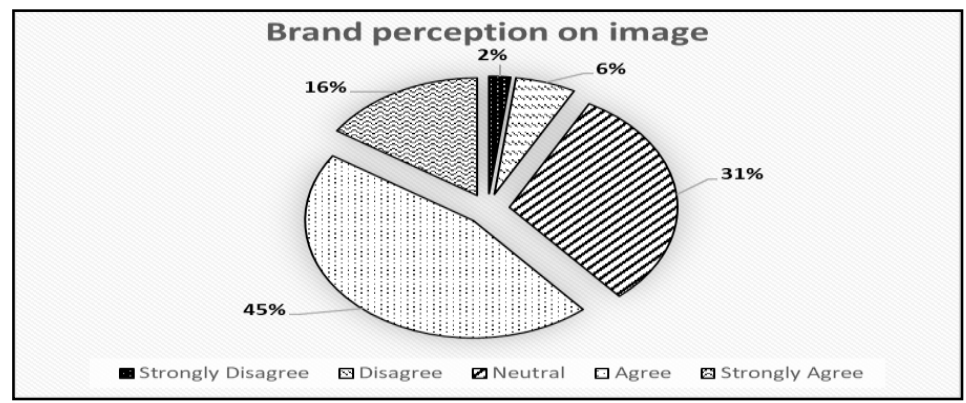

As it is shown in figure 14, the result shows $48 \%$ of the respondents agree to the perception of brand preference. Besides, $28 \%$ of the respondents are Neutral and $19 \%$ of the respondents strongly agree to the brand perception of brand preference. Where else, $4 \%$ of the respondents disagree and $2 \%$ of the respondents strongly disagree to the perception of brand preference.

Figure 14: The Brand Perception on Preference

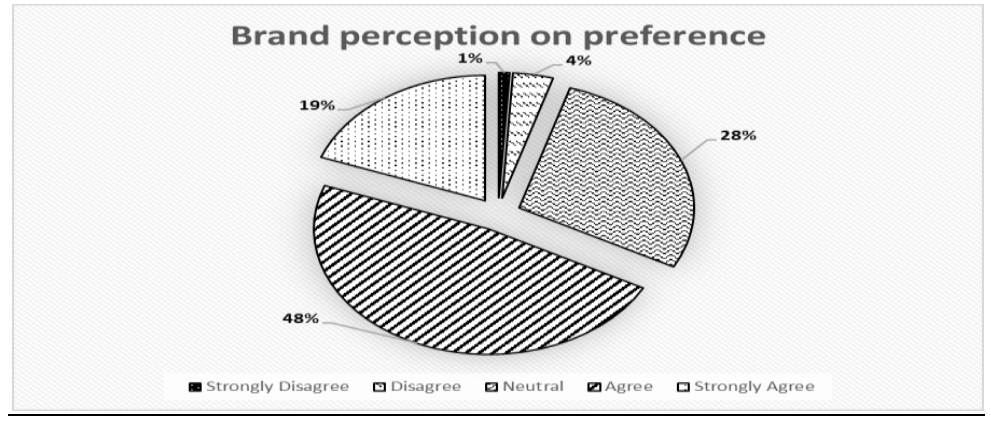

As it is shown in figure 15, the results show $47 \%$ of the respondent agree to the perception on brand satisfaction. Besides, $26 \%$ of the respondents are Neutral and $23 \%$ of the respondents chooses strongly agree to the perception on brand satisfaction. Where else, $4 \%$ of the respondents disagree and $0 \%$ of the respondent are strongly disagree.

Figure 15: The Brand Perception and Brand Satisfaction

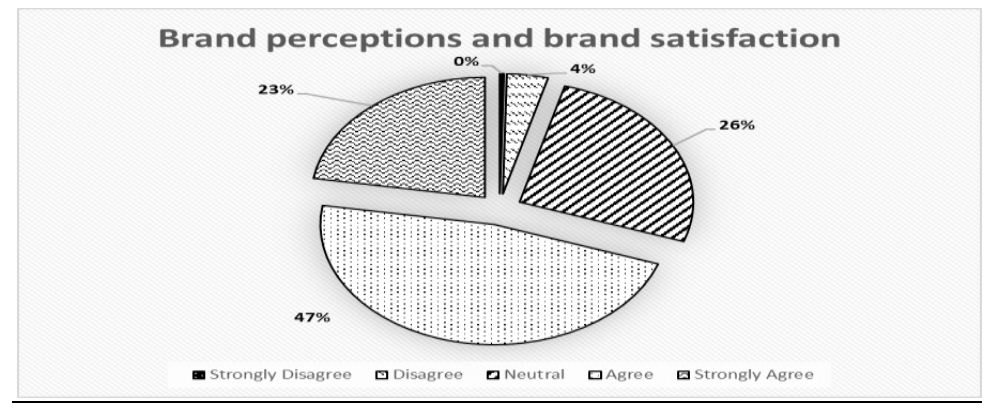

\section{Discussion}

In this study, there were 377 respondents that had filled the questionnaires. Most of the respondents were in the 18 to 30 years old group and educational background was STPM/PRE-U/Diploma. Respondent mostly were female and applied skin care products as their routine. Out of 377, the percentage of married status of respondent was slightly more while for occupation most of them were still students. 
Based on the alpha test the results show, in the reliability test, quality, promotion, image, preference and brand satisfaction are $0.848,0.906,0.830,0.902$ and 0.838 respectively. All the above tests result show that Cranach's Alpha was more than 0.80. Therefore, all the items in measuring the five variables are reliable. Analysis results show that this study is reliable. The independent variable (brand satisfaction) has strong and positive correlation with three of the independent variables (quality, image and preference). Though multiple regressions, brand satisfaction also has significant and positive relationship with three of its independent variables (quality, image and preference). Independent variable "promotion" has positive but weak correlation with brand satisfaction of skin care products. However, promotion is not statistically not significant with brand satisfaction on skin care products.

According to the information collected from data, it provides the evidences that the independent variable has a strong positive relationship with the dependent variable where the independent variable is the factor that influences the dependent variable. This business research study focuses on the local skin care products of brand perception on product quality, promotion, image and preference. These four factors of brand perceptions are independent variables; and the one dependent variable is brand satisfaction. In our study, the relationships between these four independent variables and brand satisfaction on local skin care products have been examined by our group members. Brand perceptions play an important role in brand satisfaction for the consumers of local skin care products. Therefore, the understanding of changing brand perceptions and brand satisfaction in each local skin care industry is conducted in this business research. The results of this research implies that brand perception on product quality, promotion, image and preferences have a positive relationship with brand satisfaction of local skin care products. The results agreed the previous findings of Shima et al. (2018) that most of the Malay students considered Halal, product safety, brand, price, product safety and quality as the most important factors when purchasing skin care products The findings also supported that there were other factors that influence customer to purchase a product such as quality, brand, price, advertisement and packaging (Anjana et al., 2018)). The results were also consistent with Kabuet al. (2017) that customer satisfaction was based on cultural, social, personal, and psychological factors. Moreover, this research confirmed another previous study that product quality, brand service quality, brand value and brand image, were others factors that influenced brand loyalty. Customer satisfaction, service quality and customer value are most important as indicators of the customers experience with the product and services (Haemoon, 2017), which was also consistent with Chan et al. (2016) that there was a relationship between brand loyalty and determinants of brand loyalty that focused on brand image, quality, price and promotion.

Lastly the results agreed the previous findings of Bayah et al. (2016) that most of the customers are aware of Halal certification on product skin care and choose them. The results also supported that students tend to change the brands of cosmetic products; lack awareness of the impact of cosmetic products on the health among students and lack general information in cosmetic products. (Aishah et al. (2016). Concisely, it can be seen that the most important factor for customers when purchasing skincare products is the quality of it. Besides that, the information source is most effective in decision making, varies because of the performance of the brand, the advertisements, achieving its practical functions, the preference and the experiences of using the brand.

\section{Implication of the Study}

This research has been conducted to examine the factors that influence the customers' satisfaction on the quality of local skincare products. There are five factors that can influence customers' satisfaction on the quality of local products which are brand perception on quality, promotion, preference, image and brand of product satisfaction. The information that has been obtained from this research study can help those marketers and companies to improve their performance and understand the customers' need and wants. The implications of the study are described as follows.

The factor brand perception on quality and product satisfaction of brand, the result found that product quality and product satisfaction had a relationship to influence customers' satisfaction. Product quality is an important factor to attract customers. Good product quality will make the customers satisfied and 
thus they will continue to purchase the product as well as encourage word-of-mouth publicity. Many past studies like Mano \& Oliver (1993), Oliver (1980), Tsiotsou (2006) and Weaver \& Brickman (1974) proposed that the perception of quality of performance was determined directly or through a gap between perceived and expected outcome, could create a positively relationship with satisfaction. Based on the statistical results from this research, most of the customers agreed that a high quality of the skin care products revealed that customers were satisfied toward particular brands. The impact of the results local skin care product indicates companies should improve their products to ensure they are in good quality. When the product is in good quality, the consumer's perception of the skin care product will be good as well. Then, the consumer will be satisfied the products is good.

The factor related to brand perception on image and preference, the result found that these two factors also have strong relationship to influence customers' satisfaction. In a previous study, Hsieh, Pan, \& Setiono (2004: 252) claimed that thriving brand image allowed people to recognize their requirements that they are pleased with the brand and distinguish it from other competing brands. As a result, this enhances peoples buying possibility. In other words, it means the relationship between brand perception on image and brand satisfaction on skin care products are highly correlated. While, brand perception on preference of product is important to customer, they need to have a clear perception of the brand before they have satisfaction toward the brand. Literatures indicated that more experience using the the product, the greater the likelihood of giving attention to a particular brand that brings satisfaction to them (Devaraj, Fan, \& Kohli, 2006)). From survey that we conducted, customers agreed that brand perception on image and preference had strong relationship to influence customers' satisfaction. The impact of this factor on the local skin care product marketer and company is that they can improve the marketing strategies, associated with brand positioning plan and preserve good brand image and brand preference.

The factor related to brand perception on promotion, indicated that promotion is important for every business. It plays a key role in business by promoting and persuading consumers' needs to purchase these products or service. Currently, there is an increase in rivalry among skin care products in the global market. In previous studies, the marketers tried their efforts to attract more consumers by using expensive ways to promote their products or services. The Lack of advertisements may not attract customers to spend as they may not meet their requirements. From our survey, we could identify that local skin product company has improved the way to their promote products or services. The impact of promotion for local skin care product company is a costly activity in the marketing plan but the return from investment may be low. As such the company has to focus on the other three fields which are the quality, image and preference.

The significance of this study is how it contributes to customers by highlighting the qualities of Ainaa Skincare. It is to show that effect on how satisfied their customers are with the products in terms of ingredients, branding, quality and efficiency in what the product can do to the buyer's skin and whether the outcome is worth the price. Therefore, the significance of this study is important to Malaysian citizens and the users of local skincare products.

For future researchers, if they are conducting their research which is interrelated to this topic, this study could benefit them as they will be able to find out the relevant information easily. Furthermore, it will benefit the researchers who are going to conduct this research study in Malaysia. In conclusion, the marketer can have a better understanding of the demographic profile to help them have a good target market. Lastly, this study will bring benefit to the consumers as it focuses on the quality of local skincare products and also benefits the local manufacturers in their research and development. A study should provide a result either it is good or bad for the respondents. Before starting a study, recognize something that might be a limitation as what is to be tested or what possible results may be the outcome. It may be because by specific constraints on the study population. It is maybe an ultimate effect as what the outcome will be.

The impact of implication is another type of limitation that should be considered. Although a study has a good or strong design and excellent statistical analysis, it can suffer from limited impact. An example of limited impact is on regional focus, being to specific, or the field being only conducive to 
incremental finding, A project may use a large fund to prepare it, and a lot of time need to be spent such as location of survey. In general, more resources need to be used to make this project happen as planned.

Financial limitation makes it harder to complete the research. For example, using certain online survey forms that need to be paid before using. To get a survey form to be answered, it needs to be sent to Bangi which takes a long time to arrive. Therefore, it will become a gamble if the person in charge for the survey questionnaire did not apply for a full permission to conduct the study. It will be a waste of time if it is not e approved.

\section{Conclusion}

In conclusion, the study concludes that the quality and presentation of a product are very important. It is also important that you give very good customer service to please the customers whilst shopping. This boosts up the image status of the product, therefore giving a well-known reputation as a great company to buy the products. It is relevant to investigate the relationship between customer satisfaction and the quality of services of local product. However, one avenue for further study would be research into the specific experiences and perspectives of the customers who have had positive or negative experiences of the quality of services of the product. Furthermore, researchers shall find out what chemicals in the product that are particularly not suitable for a skincare. This will in fact, help in terms of increasing the quality of the research and therefore Further studies may show more reliable results in terms of proven interviews from customers' experiences to support the analysis from the quantitative method.

\section{References}

Aishah Ahmad \&MerduwatiHashim (2016). Factor influencing customers' satisfaction and brand's loyalty in cosmetic product among students.Journal of Information Management, 2 (1) Retrieved from https://researchhub.uitm.edu.my/pdf/DrDang.pdf

Anjana, S, S \& Amrita Vidyapeetham (2018).Factors influencing cosmetic buying behaviour of consumers. International Journal of Pure and Applied Mathematics, 118, 453-459.

Bayah Ahmad \&Azizah Omar (2016). Influence of attitude on consumers' behavioural intention toward Halal cosmetic in Malaysia. Journal of Business Innovation JurnalInovasiPerniagaan, 1. Retrieved from http://www.kuim.edu.my/journal/index.php/JBI/article/download/138/122

Chan, Y.Y., \&ShaheenMansori, (2016). Brand loyalty is important is one of important aspect which keep the business running. Journal of Marketing Management and Consumer Behavior, 1. Retrieved from https://journal-of-marketing-management-and-consumerbehavior.com/index.php/JMMCB/article/download/3/3

Eftimiya, S. (2014). Consumer behaviour towards green skin care cosmetic products. (Bachelor Thesis, Seinajoki University) Retrieved from https://www.theseus.fi/bitstream/handle/10024/70630/Salo_Eftimiya.pdf

Haemoon, Kim, O. K., (2017). Customer satisfaction, service quality, and customer value: years 20002015. International Journal of Contemporary Hospitality Management, 29(1). Retrieved from https://www.researchgate.net/publication/312651327_Customer_Satisfaction_Service_Quality_ and_Customer_Value_Years_2000-2015/download

Kabu, K., \&Soniya, M. (2017). Customer satisfaction and customer loyalty. (Degree Program in Business Management, University of Applied Sciences), Retrieved from https://core.ac.uk/download/pdf/161421179.pdf

ShahidaAziz, ShaharJusoh\&HarithAmlus (2017). Investigating critical success factor of brand loyalty: A Meta-data Analysis Approach [International Review of Management and Marketing]. 7, 233237.

Shima Rani \& Devi Krishanan (2018). Factor that influence Malay student in purchasing skincare products in Malaysia. Journal of Business and Retail Management Research (JBRMR), 13. 
Viorica, P., Alina, S., Simona, D. (2014). The quality control of some dermo-cosmetics products. 25 (2), $85-90$

\section{Authors' Details}

1. Wan Nur Afiqah Binti Wan Abd Hamid, Muhammad Syahmi Bin Azahari, Noor Maisarah Binti Mohd Noor Azam, Nur AimieKamalia Binti Kamalrozaman, Nurdiyana Binti Che Kamal, Phoebe Cherng Fei Min. These authors were Diploma final year students from University of Malaya Centre for Continuing Education (UMCCeD). This was a group work for Business Research Methodology UDE 2012 which was supervised by Mr. Isai Amutan Krishnan and Ms. Vimala Davy G. Ramiah and Ms. Sio Ching Hee who contributed significantly for completing this final year project.

Address: Wisma R\&D University Malaya, Jalan Pantai Baharu, 59100 Kuala Lumpur, Federal Territory of Kuala Lumpur

2. Vimala Davy G. Ramiah is currently the head of department of the Department of Staff Development at Institute Aminuddin Baki, Sarawak Branch in Kuching, Sarawak. She was prior to this the Head of Unit at the Schools and Sports Divisions of the Ministry of Education in Putrajaya. She has more 32 years of working experience in the field of education with the Ministry of Education, Malaysia. Her research interests are in communication, applied linguistics and Teaching English as a Second Language.

Email:vimala@iab.edu.my, HP: 0192194642

Address: Institut Aminuddin Baki Sarawak Branch, Jalan Sultan Tengah, 93050 Kuching, Sarawak.

3. Sio Ching Hee: Lecturer/Trainer, ELM Business School, HELP University, Jalan Sri Semantan 1, Off Jalan Semantan, Bukit Damansara, 50490 Kuala Lumpur, Malaysia.

4. Isai Amutan Krishnan : Senior Lecturer, School of Liberal Arts, Science and Technology, PERDANA University,Suite 5.3 5th Floor Wisma Chase Perdana Jalan Semantan Damansara Heights, Wilayah Perseketuan, Malaysia. 